\section{Nyrens plass i revmatologien}

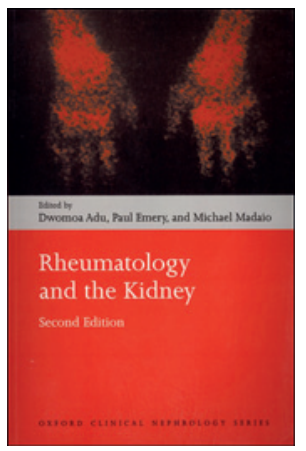

Dwomoa Adu, Paul Emery,

Michael Madaio, red.

Rheumatology and the kidney

2. utg. 466 s, tab, ill. Oxford: Oxford University

Press, 2012. Pris GBP 50

ISBN 978-0-19-957965-5

Boken er andre utgave $i$ et fagfelt hvor det har skjedd mye siden første utgave i 2001. Den gir en god dekning av revmatologien som et fag med stor bredde. Målgruppen er i hovedsak revmatologer og nefrologer, men også andre med spesiell interesse for autoimmune bindevevssykdommer. Forfatterne har invitert 55 bidragsytere til de enkelte kapitlene, som må sies å være helt i front innen sine fagfelt.

Nyreaffeksjon er hyppig forekommende ved en rekke revmatologiske sykdommer. Siden revmatologiske lidelser ikke bare har nyren som utgangspunkt, er dekningen av de ulike revmatologiske sykdommene vesentlig bredere enn bare omtale av nyrens rolle. Selv om det blir noe misvisende med henblikk på tittelen, er det en styrke. Den brede generelle gjennomgangen av de ulike sykdomskategoriene, med kliniske særtrekk, diagnostiske kriterier, histopatologiske forandringer, immunologiske aspekter og til slutt behandling, er omfattende og faglig godt oppdatert. Det er en systematisk gjennomgang av de ulike tilstandene med «Take home points» som kapittelavslutning. Forfatterne har fått med seg de siste årenes store kontrollerte studier innen ulike deler av revmatologien som har vært vesentlig for behandling av lupusnefritt og ANCA-assosierte vaskulitter. Kapitlene om revmatologiske og renale komplikasjoner ved virale hepatitter og hiv er korte, men oversiktlige. Videre er nyretoksisitet ved bruk av ikkesteroide antiinflammatoriske legemidler og andre hyppig forekommende analgetika i revmatologien viet egne kapitler. Til slutt er revmatologiske komplikasjoner ved langtkommen nyresvikt kort beskrevet.

Når det kommer til den spesifikke omtalen av nyreaffeksjon som leder til tap av nyrefunksjon og nyreerstattende behandling, er boken svak. Fremdeles vil en del pasienter med aggressiv revmatologisk lidelse og nyreaffeksjon ende opp med nyresvikt i endestadium. I Norge betyr det i praksis at disse pasientene tilbys transplantasjon. Det er et problem for pasienter som blir transplantert, at de kan få residiv av den revmatologiske grunnsykdommen i den transplanterte nyren. Ny litteratur er ikke med.

Det mangler et innledende samlende kapittel som kunne gitt leseren en generell informasjon om likhetstrekk ved autoimmune revmatologiske sykdommer og nyreaffeksjon. Den generelle layouten og spesielt mangelen på pedagogiske virkemidler er skuffende. Selv om fargeillustrasjoner kan være kostbare, burde i alle fall noen av patologisnittene vært gjengitt i farger. Flere av kapitlene har betydelig overlapp, særlig lupuskapitlene. Hovedforfatterne tyr til den løsningen at de lar forfatterne av de ulike kapitlene legge på en «stjerne» med kommentarer til viktige referanser. Stjernene er ofte knyttet til forfatternes egne arbeider.

Boken er et godt oppslagsverk, men er ikke egnet til å lese fra perm til perm som en lærebok. Det er tvilsomt om boken bør være førstevalg ved litteratursøk på behandling av de aktuelle sykdommene, særlig ved lupusnefritt hvor behandlingen er uoversiktlig fremstilt. Imidlertid er vaskulittkapitlet til David Jayne strålende godt skrevet. Dette, sammen med flere av de andre beste kapitlene, gjør det verdt å ønske seg boken på kontoret!

Gudrun E. Norby

Medisinsk avdeling

Lovisenberg Diakonale Sykehus

\section{Frigjørende om sykehusarkitektur}

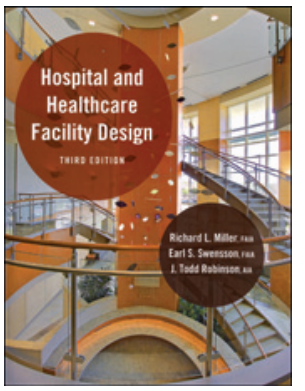

\author{
Richard L. Miller, Earl S. Swensson, \\ J. Todd Robinson
}

Hospital and healthcare facility design

3. utg. 399 s, ill. New York, NY: W.W. Norton,

2012. Pris USD 115

ISBN 978-0-393-73309-9

Vi påvirkes av våre omgivelser både når vi er friske og syke. Det har vært etablert kunnskap i århundrer. Psykologiske, sosiale og fysiske aspekter av miljøet $\mathrm{i}$ sykehus har effekter på behandlingsresultat og pasienttilfredshet. Forfatternes ambisjon er å gi innspill til sykehusdesign med mål om å skape «healing environments for those who are ill, and comfort and wellness for all who use them».

Forfatterne er arkitekter i et av USAs ledende firmaer på sykehusdesign. Boken begynner med en historisk oversikt over de ulike trendene som har vært i fagfeltet. Den avsluttes med en diskusjon om utfordringer for de neste tiårene. Sammen med medisin har sykehusarkitektur gjennomgått en rekke paradigmeskifter. De gamle, fremmedgjørende og skremmende sykehusmastadontene vil endre seg til fasiliteter hvor pasienter og pårørende skal føle seg som velkomne og trygge gjester. Samtidig skal byggene være effektive, økonomiske, «grønne» og fleksible - fleksible for raskt å kunne omgjøres for å møte nye utfordringer og pasienttyper som sikkert vil komme.

I detalj kommer forfatterne med innspill for design av ulike typer avdelinger. Et eget kapittel omhandler muligheter, problemer og løsninger for ombygging av gamle strukturer. Hvert kapittel har en rekke skisser, utkast, snitt, endelige planløsninger, situasjonsplaner og utomhusplaner for de enkelte avdelingstypene og hele sykehuskompleks.

Bidragsyterne omtaler kun sykehus fra USA. Trender fra resten av verden ville gjort boken mer helhetlig. En del avdelingstyper som geriatri, psykiatri og sykehjem er mangelfullt beskrevet. Forfatterne har ambisjon om å beskrive design som er evidensbasert. De beskriver en rekke viktige funn fra kvalitative studier, men igjen har de glemt at det er en verden utenfor USA. En omfattende referanseliste har samme mangler. De få randomiserte studiene av effekter av ulik sykehusdesign som finnes, er ikke omtalt.

Dette er en god og grundig innføring i prinsippene for dette fascinerende fagfeltet. Boken vil derfor være nyttig for sykehusadministratorer, planleggere og arkitekter. Den er også verdifull for alle helsearbeidere som deltar på et eller annet nivå i sykehusbygging eller rehabilitering. Boken har hundrevis av fargebilder fra ulike deler av sykehus og omgivelser. Disse vil være til inspirasjon for alle som har noe med sykehus å gjøre. Våre tanker er styrt av myter og begrensninger, og mange har sterke meninger om arkitektur, design og interiør i egen avdeling. Stygt og pent er subjektive begreper. Alle bildene inspirerer til nye ideer om hvordan min avdeling kan bli, hva som er mulig, hva som er lov, og hvilke utrolige fargekombinasjoner som faktisk inspirerer. Mange vil finne boken frigjørende for fantasien og tanken.

\section{Arne Vaaler}

Institutt for nevromedisin

Norges teknisk-naturvitenskapelige universitet 